\title{
Efficacy of Crude Leaf Extracts of Aloe secundiflora on Selected Enteric Bacterial Pathogens and Candida albicans
}

\section{Rachuonyo $\mathrm{HO}^{1 *}$, Ogola $\mathrm{PE}^{2}$, Arika $\mathrm{WM}^{2}$ and Wambani $\mathrm{JR}^{3}$}

${ }^{1}$ Department of Microbiology, Kenyatta University, Kenya

${ }^{2}$ Department of Biochemistry and Biotechnology, Kenyatta University, Kenya

${ }^{3}$ Department of Medical Laboratory Sciences, Kenyatta University, Nairobi, Kenya

\begin{abstract}
The main aim of the study was to determine the antimicrobial effect of methanolic leaf extract of Aloe secundiflora against four Gram-negative bacteria (Shigella flexineri, Salmonella typhi, Escherichia coli and Enterococcus faecalis), one Gram-positive bacteria (Staphylococcus aureus) and on one fungal pathogen (Candida albicans) by Kirby Bauer method. The extract was found to be more effective against all the bacterial pathogens and Candida albicans using ciprofloxacin as the standard antibiotic for Gram-negative bacterial pathogens, Vancomycin for Staphylococcus aureus and Fluconazole for Candida albicans with an MIC range of $3-11 \mathrm{mg} / \mathrm{ml}$. the preliminary analysis for the extracts confirmed the presence of alkaloids, saponins, tannins and flavonoids. Our study revealed that, the extract from Aloe secundiflora leaf can be used in treating the diseases caused by the bacterial pathogens.
\end{abstract}

Keywords: Aloe secundiflora; Kirby Bauer; MIC; Ciprofloxacin; Vancomycin

\section{Introduction}

Medicinal plants are used by almost $80 \%$ of the world's population for their basic health care because of their low cost and ease in availability [1]. From the dawn of civilization, people have developed great interest in plant based drugs and pharmaceutical products [1]. In the last few decades many bacterial organisms have continued to show increasing resistance against current antimicrobial agents [2]. Herbal drugs made from medicinal plants have been used from ancient times to treat various diseases and their antimicrobial properties make them a rich source of many potent drugs [3]. The use of herbal medicinal plants has always played a positive role in the control or prevention of diseases such as diabetes, heart disorders and various cancers [4]. Some medicinal plants have been used in production of various drugs singly or in combination and even as principal raw material for the production of other conventional medicines [2]. Aloe extracts have been used for many centuries for their curative and therapeutic properties [5]. Aloe species have antibacterial, antifungal, anticancer, antiviral and immunomodulatory properties [6]. Aloe secundiflora leaf components have been credited for antibacterial, antifungal and antiviral and antihelmintic medicinal properties [7]. Aloe secundiflora has been used in treating ailments including; chest problems, polio, malaria and stomach ache by herbalists in the Lake Victoria region in Kenya [8].

Aloe secundiflora leaf components have been credited for antibacterial, antifungal and antiviral and antihelmintic medicinal properties [9]. Aloe products have also been used in pharmaceuticals, cosmetic and food industries [10]. The main of the study was to provide insight about the antimicrobial activities of Aloe secundiflora leaf extracts and their use in treatment of bacterial or fungal infections.

\section{Materials and Methods}

\section{Plant material collection}

The fresh plant material of Aloe secundiflora was collected at Kenyatta University Arboretum. Voucher specimen was prepared and deposited in the university herbarium in Plant Sciences Department for future reference. The plants were brought to the laboratory and thoroughly washed in running water to remove debris and dust particles and then rinsed using distilled water and finally air dried.

\section{Preparation of plant extract}

The air dried plant materials were tause into powder and soaked in methanol for 72 hours, placed in a Gallenkamp shaker at 65 revolutions per minute. The contents were homogenized and filtered using whatman filter paper no. 1 . The filtrate was poured into a round bottom flask and concentrated using a vacuum evaporator and stored in a labelled amber glass bottle at room temperature away from light and heat before being used for antimicrobial efficacy test.

\section{Antimicrobial susceptibility testing}

The microorganisms used were clinical isolates of Escherichia coli, Salmonella typhi, Enterococcus faecalis, Staphylococcus aureus, Shigella flexineri, Enterococcus faecalis and Candida albicans obtained from Kenyatta University Health Centre Laboratory, Nairobi. The test microorganism were concentrated by comparing it with a $0.5 \mathrm{McF}$ arland standard. Discs of 6 milliliters were prepared from whatman no.1 filter paper. The discs were sterilized by autoclaving. After sterilization the moisture discs were dried on hot air oven at $50^{\circ} \mathrm{C}$ [11]. The discs were impregnated with the extract from the highest concentration of 1000 $\mathrm{mg} / \mathrm{ml}$ to the lowest concentration of $1 \mathrm{mg} / \mathrm{ml}$ by subsequently halving the dilutions [12]. Dimethyl sulphoxide (5\%) was used in impregnating the extracts on the discs. Antimicrobial efficacy test was carried out using Kirby Bauer method [13]. Hektoen agar was used in the spread

*Corresponding author: Hibert Opinde Rachuonyo, Kenyatta University, Microbiology, Eldoret, Riftvalley 30100, Kenya, Tel: +2540715407214; E-mail: hibton@yahoo.com

Received December 11, 2015; Accepted March 30, 2016; Published March 31, 2016

Citation: Rachuonyo HO, Ogola PE, Arika WM, Wambani JR (2016) Efficacy of Crude Leaf Extracts of Aloe secundiflora on Selected Enteric Bacterial Pathogens and Candida albicans. J Antimicro 2: 112. doi:10.4172/2472-1212.1000112

Copyright: @ 2016 Rachuonyo HO, et al. This is an open-access article distributed under the terms of the Creative Commons Attribution License, which permits unrestricted use, distribution, and reproduction in any medium, provided the original author and source are credited. 
plate technique where the clinical isolates were spread using sterilized cotton wool swabs. They were then exposed to discs impregnated with Aloe secundiflora leaf extract. The discs were placed with equal distance between them on agar plates inoculated with the bacterial pathogens and Candida albicans. Positive control discs containing ciprofloxacin was used for the bacteria's Escherichia coli, Salmonella typhi, Enterococcus faecalis, Shigella flexineri; Staphylococcus aureus, and fluconazole for Candida albicans. A negative control of discs impregnated with 5\% DMSO was also used. The Petri dishes were incubated at $37^{\circ} \mathrm{C}$ for 24 hours.

The experiment was carried in duplicates and the average diameter of zones of inhibition formed determined. Minimal inhibitory concentration (MIC) was determine using microplate wells [14]. 100 $\mu \mathrm{l}$ of $250 \mathrm{mg} / \mathrm{ml}$ of methanol extract was added to $100 \mu \mathrm{l}$ of sterile bacteriological peptone in the first well of the 96 well micro plate and mixed well with a micropipette. $100 \mu \mathrm{l}$ of this dilution was transferred subsequently to wells two folding each dilution of the original extract. An inoculum of $100 \mu \mathrm{l}(0.5 \mathrm{McFarland}$ standard $)$ of overnight clinical cultures of; Escherichia coli, Salmonella typhi, Staphylococcus aureus, Shigella flexineri, Enterococcus faecalis and fungus Candida albicans were added in each of the wells. Triplicate of each micro plate were made and the procedure repeated for each of the test organisms. The plates were then incubated at $37^{\circ} \mathrm{C}$ for 24 hours. After incubation 40 $\mu \mathrm{l}$ of $0.2 \mathrm{mg} / \mu \mathrm{l}$ of INT was added in each of the wells and the plates examined after an additional 60 minutes of incubation. Growth was indicated by a red colour (conversion of INT to formazan). The lowest concentration at which the colour was apparently invisible as compared to the next dilution was taken as the minimum inhibitory concentration [15]. Minimum bactericidal concentration (MBC) and minimum fungicidal concentration (MFC) was determined by taking $100 \mu \mathrm{l}$ of suspension from micro plate wells that demonstrated no growth and inoculating on agar plates. The plates were incubated at $37^{\circ} \mathrm{C}$ for 24 hours. In the case where there was no bacterial growth and also not greater than the minimum inhibitory concentration was used to determine the maximum bacterial concentration and maximum fungicidal concentration [15].

\section{Results}

In this study the antimicrobial activity of Aloe secundiflora leaf was evaluated for antimicrobial activity against the selected human pathogens. Methanol was used in the extraction process and the antimicrobial activity determined using the Kirby Bauer method. Tables 1-3 shows the antimicrobial activity of the extract against bacterial pathogens and fungus Candida albicans. The results indicate that the extract from Aloe secundiflora was active against all the tested microorganisms. The positive control (ciprofloxacin) produced significantly sized zones of inhibition against the bacterial pathogens (ranging from 20-25 mm); fluconazole against Candida albicans (28 $\mathrm{mm}$ ). Negative control dimethyl sulphoxide (DMSO) produced no zone of inhibition. The extract showed good antimicrobial activity against
Shigella flexineri and Enterococcus faecalis producing highest zone of inhibition $(18 \mathrm{~mm})$ in both. The extract showed minimal antimicrobial activity $(13 \mathrm{~mm})$ against Staphylococcus aureus.

The MIC of the extracts ranged from 3-11 $\mathrm{mg} / \mathrm{ml}$ while the MBC ranged from $7-13 \mathrm{mg} / \mathrm{ml}$ as indicated in Table 3. Aloe secundiflora extract was more active against Shigella flexineri and Salmonella typhi in low concentrations as compared to its activity against Staphylococcus aureus. The extract had a strong bactericidal capability against Salmonella typhi and Shigella flexineri in low concentrations (Table 3)

\section{Discussion}

Medicinal plants have been used for a long time in traditional medicine to treat diseases. Over 122 compounds currently used in modern medicine have been derived from plants and $80 \%$ of their derivatives have had an ethno medicinal use [16]. The use of herbs to treat diseases is common among the non-industrialized societies where they are seen as more affordable than purchasing the modern pharmaceuticals [17]. The world health organization has estimated that 80 percent of population of Asia and African countries presently use herbal medicine for some of their primary health [17]. In this study, the antimicrobial potency of Aloe secundiflora was tested against Gram negative bacteria (Escherichia coli, Salmonella typhi, Enterococcus faecalis and Shigella flexineri), Gram positive bacteria (Staphylococcus aureus) and fungal pathogen Candida albicans. The plant extract showed pronounced antimicrobial activity against Salmonella typhi and Enterococcus faecalis and less activity against Staphylococcus aureus (Table 1). When the extract was used in low concentrations, it showed pronounced inhibition activity against Shigella flexineri and Salmonella typhi when compared to Staphylococcus aureus. The antimicrobial activity of the Aloe secundiflora extract was less active against Staphylococcus aureus as compared to all the bacterial pathogens and fungal pathogen used. This showed that the extract from the plant had antimicrobial potential against the enteric bacterial pathogens and Candida albicans. Similar studies carried out have shown that extracts from Aloe secundiflora has antimicrobial potential against both fungal and bacterial pathogens $[7,18]$. Medicinal plants have known to produce secondary metabolites which have been thought to be responsible for the antimicrobial activity caused by their extracts. Some of the secondary metabolites such as alkaloids, polyphenols, glycosides and terpenes have shown antimicrobial activity against bacterial pathogens [19]. From the study, the plant extract from Aloe secundiflora contained saponins tannins, alkaloids and flavonoids. The phytochemicals present might be responsible for the antimicrobial activity. Tannin is a stringent vegetable product found in a wide range of plants parts ranging from the barks, roots, seeds, fruits, leaves, galls and roots [20]. Tannins are generally found in plants and they are thought to function as chemical defenses against pathogens and herbivory [21]. Tannins have shown to be responsible for inhibition of fungal and bacterial growth [22,23]. Flavonoids or bioflavonoids are secondary metabolites of plants that chemically have a general structure of 15 carbon skeleton consisting

\begin{tabular}{|c|c|c|c|}
\hline Microorganisms & Extract & Ciprofloxacin & Fluconazole \\
\hline Escherichia coli & $17 \pm 1.38 \mathrm{~mm}$ & $20 \pm 2.47 \mathrm{~mm}$ & $0.0 \mathrm{~mm}$ \\
\hline Salmonella typhi & $16 \pm 0.68 \mathrm{~mm}$ & $24 \pm 0.35 \mathrm{~mm}$ & $0.0 \mathrm{~mm}$ \\
\hline Staphylococcus aureus & $13 \pm 0.17 \mathrm{~mm}$ & $25 \pm 1.06 \mathrm{~mm}$ & $0.0 \mathrm{~mm}$ \\
\hline Shigella flexineri & $18 \pm 0.38 \mathrm{~mm}$ & $22 \pm 1.06 \mathrm{~mm}$ & $0.0 \mathrm{~mm}$ \\
\hline Enterococcus faecalis & $18 \pm 0.35 \mathrm{~mm}$ & $22 \pm 1.06 \mathrm{~mm}$ & $0.0 \mathrm{~mm}$ \\
\hline Candida albicans & $17 \pm 0.38 \mathrm{~mm}$ & $0.0 \mathrm{~mm}$ & $28 \pm 3.18 \mathrm{~mm}$ \\
\hline
\end{tabular}

Table 1: Antimicrobial activity of Aloe secundiflora leaf extract against bacterial pathogens and fungus Candida albicans. 


\begin{tabular}{|c|c|c|c|}
\hline Name of test & & & \\
\hline Saponins & Tannins & Alkaloids & Flavonoids \\
\hline+ & + & + & + \\
\hline Key: $(+)$ present & & & \\
\hline
\end{tabular}

Table 2: Phytochemical analysis of leaf extract.

\begin{tabular}{|c|c|c|c|c|c|c|}
\hline & E. coli & S. typhi & S. aureus & S. flexineri & E. faecalis & C. albicans \\
\hline MIC & 9.1 & 5.5 & 10.2 & 3.7 & 7.0 & 8.1 \\
\hline MBC & 10.4 & 7.3 & 12.9 & 8.0 & 9.7 & 9.0 \\
\hline
\end{tabular}

Table 3: Inhibitory concentrations $(\mathrm{mg} / \mathrm{ml})$ of the extract against microorganism.

of two phenyl rings and a heterocyclic ring [24]. Flavonoids are usually subdivided into anthoxanthins, flavanones, flavanols, flavans, and anthocyanidin [25]. Specific compounds isolated from medicinal plants such as anthraquinones and dihydroxyanhraquinones as well as saponins have shown to have antimicrobial activity [26-28]. Flavonoids from some medicinal plants have been found to inhibit the synthesis of the nucleic acids, cause permeability of the inner bacterial membrane and a dissipation of the membrane potential of Gram negative and Gram positive bacteria [29]. Some of the bioactive components that have been isolated from flavonoids have been found to contain antifungal and antibacterial activities [30,31]. Additional in vivo studies have shown that flavonoids can be used as pharmaceutical drugs for bacterial infections or through dietary intake to offer protection against infection [32]. Alkaloids are a group of natural occurring compounds that contain nitrogen and can be neutral or have weakly acidic properties [24]. Alkaloids have a great antimicrobial against bacterial pathogens such as Escherichia coli, Klebsiella pneumonia, Staphylococcus aureus and Pseudomonas aureginosa [33]. Some of the purified components of alkaloids such as morphine and cordine have been found to be active not only against bacterial and fungal pathogens [34,35]. Other similar studies carried out on alkaloids extracted from a variety of medicinal plants have showed a great antimicrobial activity against both Gram negative and Gram negative bacteria and also showed great antifungal activity [36]. Saponins are a class of chemical compounds found in various plant species and they are amphipathic glycoside grouped structurally by having one or more hydrophilic glycosides moieties combined with lipophilic triterpine. There has been evidence of presence of saponins in traditional medicine preparations where administration is through oral means that is expected to lead to the hydrolysis of glycosides from terpenoids [37]. Studies carried out have shown medicinal plant extracts fractions rich in saponins are effective against microorganisms such as Escherichia coli, Salmonella typhi, Aeromonas hydrophilia and other fungal pathogens such as Candida albicans [38]. Saponins antimicrobial activity is attributed mainly to its capability of lysing microorganism's membranes rather than the surface tension of the extracellular medium [37].

\section{Conclusion}

In conclusion, the findings from the study will help in the use of herbal medicine in the treatment of diseases caused by the selected microorganism. The extract can be further purified and the bioactive components isolated which can also be a natural source of available to treat diseases caused by the microbes that have gradually developed resistance against conventionally used drugs overtime.

\section{References}

1. Irum S, Amjad H, Ummara WK, Mohammad MS (2010) Evaluating biological activities of the seed extracts from Tagetes minuta L. found in Northern Pakistan. J Med Plants Res 4: 2108-2112.
2. Gislene GF, Locatelli NJ, Paulo CF, Giuliana LS (2000) Antibacterial activity of plant extracts and Phytochemicals on antibiotic resistant bacteria. Braz $J$ Microbiol 31: 247-256.

3. Srivastava J, Lambert J, Vietmeyer N (2005) Medicinal plants: An expanding role in from Western India for potential antimicrobial activity. Indian J Pharmacol 37: 406-409.

4. Mohanta B, Chakraborty A, Sudarshan M, Dutta RK, Baruah M (2003) Elemental profile in some common medicinal plants of India. Its correlation with traditional therapeutic usage. J Rad analyt, Nuclear Chem 258: 175-179.

5. Habeeb F, Shakir E, Bradbury F, Cameron P, Taravati MR, et al. (1994) Effect of garlic on lead contents in chicken tissues. DTW 101: 157-158.

6. Holzmuller P, Sereno D, Cavalrero M, Mangot L, Dauloude S, et al. (2002) Nitric oxide mediated proteasome-development oligonuleosomal DNA fragmentation in L. amazonensis amastigotes. Infect and Immun 70: 3727-3735

7. Mwale M, Bhebhe E, Chimonyo M, Halimanii TE (2005) Use of herbal plants in poultry health management in Mushagashe small scale commercial farming area in Zimbabwe. International J Applied Vet Med 3: 163-170.

8. Kigondu EVM, Rukunga GM, Keriko JM, Tonui WK, Gathitwa JW, et al. (2009) Anti-parasitic activity and cytotoxicity of selected medicinal plants from Kenya. J Ethnopharmacol 123: 504-509.

9. Kaingu F, Kibor A, Waihenya R, Shivairo R, Mungai L (2013) Efficacy of Aloe secundiflora Crude Extracts on Ascaridia galli in Vitro. Sustain Agricul Research 2: 2 .

10. Eshun K, He Q (2004) Aloe vera: A valuable ingredient for the food pharmaceutical and cosmetic industries. Crit Rev Food Sci Nutr 44: 91-96.

11. Arunkumar S, Muthuselvam M (2009) Analysis of phytochemical constituents and antimicrobial activities of Aloe vera L. against clinical pathogens. World $\mathrm{J}$ Agricul Sciences 5: 572-576.

12. Joshua M, Ngonidzashe M, Bamusi S (2010) An evaluation of the antimicrobial activities of Aloe barberdensis, A. chabaudii and A. arborescens leaf extracts used in folk fore veterinary medicine in Zimbabwe. J Animal And Vet Advances 9: 2918-2923.

13. Newall CA, Anderson LA, Phillipson JD (1996) Herbal medicines. The pharmaceutical Press London p: 25

14. Eloff JN (1998) A sensitivity and quick microplate method to determine the minimal inhibition concentration of plant extracts for bacterial organisms. Med Plants J 64: 711-713

15. Rabe T, Mullholland D, Van Staden J (2002) Isolation and identification of antibacterial compounds from Vernonia colorata leaves. J Ethnopharmacol 80 91-94

16. Fabricant DS, Farnsworth NR (2001) The value of plants used in traditional medicine for drug discovery. Environ Health Perspect 109: 69.

17. http://www.traffic.org/medicinal-plants

18. Msoffe P, Mbilu Z (2009) The efficacy of crude extract of Aloe secundiflora on Candida albicans. African J Trad Complement Alt Med 6.

19. Springob K, Kutchan TM (2009) Introduction to the different classes of natura products. In Plant-Derived Natural Products pp: 3-50.

20. Ramakrishnan K, Selve SR, Shubha R (2006) Tannin and its analytical techniques. Ind Chemical Eng 48: 88-93.

21. Gedir JV, Sporns P, Hudson RJ (2005) Extraction of condensed tannins from cervid feed and faeces and quantification using a radial diffusion assay. J Chem Ecol 31: 2761-2773.

22. Chung KT, Wong TY, Wei CL, Huang YW, Lin Y (1998) Tannins and human health: a review, Critical Review. J food science and nutrition 6: 421-464.

23. Akiyama H, Fujii K, Yamasaki O, Oono T, Iwatsuki K (2001) Antibacterial activity of several tannins against Staphylococcus aureus. J Antimicro Chemotherapy 48: $487-491$.

24. Alan DMN, Andrew W (1997) "IUPAC Compendium of Chemical Terminology" $\left(2^{\text {nd }}\right.$ edn.) Oxford: Blackwell Scientific, UK.

25. Zhao DQ, Han CX, Ge JT, Tao J (2012) Isolation of a UDP-glucose: Flavonoid 5-O-glucosyltransferase gene and expression analysis of anthocyanin 
Citation: Rachuonyo HO, Ogola PE, Arika WM, Wambani JR (2016) Efficacy of Crude Leaf Extracts of Aloe secundiflora on Selected Enteric Bacterial Pathogens and Candida albicans. J Antimicro 2: 112. doi: 10.4172/2472-1212.1000112

biosynthetic genes in herbaceous peony (Paeonia lactiflora Pall.). Electro $\mathrm{J}$ Biotech 15.

26. Sosa GK, Alvarez VN, Lubben P, Rodriguez PLM (2006) Chrysophanol, an antimicrobial anthraquinone from the root extract of Colubrina greggii. Journal for Mexican Chemotherapy Society 50: 76-78.

27. Reynolds T, Dweck AC (1999) Aloe vera leaf gel: a review update. J Ethno Pharmacol 68: 3-37.

28. Wu YW, Ouyang J, Xiao XH, Gao WY, Liu Y (2006) Antimicrobial properties and toxicity of anthraquinones by micro calorimetric bioassay. Chinese $J$ Chemotherapy 24: 45-50.

29. Lamb AJ, Cushnie TP (2005) Errata for "Antimicrobial activity of flavonoids". In J Antimicrobial Agents 26: 343-356.

30. Galeotti F, Barile E, Curir P, Dolci M, Lanzotti V (2008) "Flavonoids from carnation (Dianthus caryophyllus) and their antifungal activity". Phytochemistry Letters 1: 44

31. Abdel-Ghani SB, Mugisha PJ, Wilcox JC, Gado EAM, Medu EO, et al. (2013) Convenient One-Pot Synthesis of Chromone Derivatives and Their Antifungal and Antibacterial Evaluation, Synthetic Communications: An Int J for Rapid Communof Synthetic Org Chem 43: 1549-1556.
32. Zamora-Ros R, Agudo A, Luján-Barroso L, Romieu L, Ferrari P, et al. (2012) Dietary flavonoid and lignan intake and gastric adenocarcinoma risk in the European Prospective Investigation into Cancer and Nutrition (EPIC) study. Am J Clinical Nutrition 96: 1398-1408.

33. Maatalah BM, Bouzidi NK, Bellahouel S, Merah B, Fortas Z, et al. (2012) Antimicrobial activity of the alkaloids and saponin extracts of Anabasis articulate. J Biotech and Pharm Res 3: 54-57.

34. Freiburghaus F, Kaminsky R, Nkunya MHH, Brun R (1996) Evaluation of Africa Medicinal Plants for their In-vitro trypanacidal activity. J Ethnopharmacol 55 $1-11$.

35. Omulokoli E, Khan B, Chabra SC (1997) Anti-plasmodial Activity of four Kenyan Medicinal Plants. J Ethnopharmacol pp: 56133-56137.

36. Garba S, Okeniyi SO (2012) Antimicrobial activities of total alkaloids extracted from some Nigerian medicinal plants. J Microbiol and Antimicro 4: 60-63.

37. Nassiri M, Hosseinzadeh $H$ (2008) Review of pharmacological effects of Glycyrrhiza sp. and its bioactive compounds. Phytother Res 22: 709-724.

38. Deshpande S, Kewatkar S, Paithankar V (2013) Antimicrobial activity of Saponins rich fraction of Cassia auriculata Linn against various microbial strains. Int Current Pharm J 2: 85-87. 